Supplement of

\title{
Staying and immobility: new concepts in population geography? A literature review
}

\section{Elisabeth Gruber}

Correspondence to: Elisabeth Gruber (elisabeth.gruber@oeaw.ac.at)

The copyright of individual parts of the supplement might differ from the article licence. 


\section{Supplement}

Full reference list of all the articles included in the meta-analysis by type of inquiry.

\section{A. Kev publication collected via database kevword search}

Adams, H.: Why populations persist: mobility, place attachment and climate change. A Journal of Interdisciplinary Studies, 37, 429-448. doi:10.1007/s11111-015-0246-3, 2016.

Allerton, C.: Stuck in the short term: immobility and temporalities of care among Florenese migrants in Sabah, Malaysia. Ethnos, 85(2), 208-223, 2020.

Ayeb-Karlsson, S., Kniveton, D. and Cannon, T.: Trapped in the prison of the mind: Notions of climate-induced (im) mobility decision-making and wellbeing from an urban informal settlement in Bangladesh. Palgrave Communications, 6(1), 1-15, 2020.

Barcus, H. R. and Shugatai, A.: Immobile populations as anchors of rural ethnic identity: Contemporary Kazakh narratives of place and migration in Mongolia. Population, Space and Place, 24, e2148, doi:10.1002/psp.2148, 2018.

Bauböck, R.: International migration and liberal democracies: the challenge of integration. Patterns of Prejudice, 35(4), 33-49, 2001.

Bihagen, E.: The Plausibility of Class Cultural Explanations: An Analysis of Social Homogeneity using Swedish Data from the Late 1990s. Sociological Research Online, 2001, 5(4), 51-67, doi: doi/10.5153/sro.530, 2001**

Blondin, S.: Understanding involuntary immobility in the Bartang Valley of Tajikistan through the prism of motility. Mobilities, 1-16, 2020.

Bélanger, D., and Silvey, R.: An Im/mobility turn: power geometries of care and migration. Journal of Ethnic and Migration Studies, 46, 3423-3440, doi:10.1080/1369183X.2019.1592396, 2020.

Champion, T., and Shuttleworth, I.: Are People Changing Address Less? An Analysis of Migration within England and Wales, 1971-2011, by Distance of Move. Popul. Space Place, 23: e2026. doi: 10.1002/psp.2026, 2017.

Clark, W. A. V., Duque-Calvache, R., and Palomares-Linares, I.: Place Attachment and the Decision to Stay in the Neighbourhood. Population, Space and Place, 23, n/a. doi:10.1002/psp.2001, 2017.

Conlon, D.: Waiting: Feminist perspectives on the spacings/timings of migrant (im) mobility. Gender, Place \& Culture, 18(3), 353-360, 2011.

Conrad Suso, C. T.: Involuntary Immobility and the Unfulfilled Rite of Passage: Implications for Migration Management in the Gambia, West Africa. International Migration, 58(4), 184-194, 2020.

Cooke, T. J.: It is not Just the Economy: Declining Migration and the Rise of Secular Rootedness: Secular Rootedness. Population, Space and Place, 17, 203. doi:10.1002/psp.670, 2011.

Cooke, T. J., and Shuttleworth, I.: The effects of information and communication technologies on residential mobility and migration. Population, Space and Place, 24, doi:10.1002/psp.2111, 2018.

Cooke, T.J., Wright, R. and Ellis, M.: A Prospective on Zelinsky's Hypothesis of the Mobility Transition, Geographical Review, 108:4, 503-522, DOI: 10.1111/gere.12310, 2018.

Coulter, R.: Wishful thinking and the abandonment of moving desires over the life course.

Environment and Planning A, 45(8), 1944-1962, 2013. 
Coulter, R., Ham, M. v., and Findlay, A. M.: Re-thinking residential mobility: Linking lives through time and space. Progress in Human Geography, 45, 1944-1962, doi:10.1177/0309132515575417, 2016.

Cresswell, T.: Towards a politics of mobility. Environment and planning D: society and space, 28(1), $17-31,2010$

Cresswell, T.: Mobilities II: still. Progress in human geography, 36(5), 645-653, 2012.

Cuervo, H., and Cook, J.: Formations of belonging in Australia: The role of nostalgia in experiences of time and place. Population, Space and Place, 25, e2214, doi:10.1002/psp.2214, 2019.

Erickson, L. D., Sanders, S. R., and Cope, M. R.: Lifetime stayers in urban, rural, and highly rural communities in Montana. Population, Space and Place, 24, e2133. doi:10.1002/psp.2133, 2018.

Farbotko, C., \& McMichael, C.: Voluntary immobility and existential security in a changing climate in the Pacific. Asia Pacific Viewpoint, 60, 148-162, doi:10.1111/apv.12231, 2019.

Forsberg, S.: The right to immobility'and the uneven distribution of spatial capital: negotiating youth transitions in northern Sweden, Social \& Cultural Geography, 20(3), 323-343, 2019.

Foster, T. B. Decomposing American immobility: Compositional and rate components of interstate, intrastate, and intracounty migration and mobility decline, Demographic Research, 37.

doi:10.4054/DemRes.2017.37.47, 2017.

Franquesa, J.: "We've Lost Our Bearings": Place, Tourism, and the Limits of the "Mobility Turn". Antipode, 43: 1012-1033. doi:10.1111/j.1467-8330.2010.00789.x, 2011.

Glick Schiller, N. and Salazar, N. B.: Regimes of Mobility Across the Globe, Journal of Ethnic and Migration Studies, 39:2, 183-200, DOI: 10.1080/1369183X.2013.723253, 2013.

Gross-Wyrtzen, L.: Contained and abandoned in the "humane" border: Black migrants' immobility and survival in Moroccan urban space. Environment and Planning D: Society and Space, 38, 887-904, 2020 .

Hjälm, A.: The 'Stayers': Dynamics of Lifelong Sedentary Behaviour in an Urban Context. Population, Space and Place, 20(6), 569-580. doi:10.1002/psp.1796, 2014.

King, R.: Migration comes of age. Ethnic and Racial Studies, 38, 2372. doi:10.1080/01419870.2015.1034744, 2015.

Kordel, S., and Weidinger, T.: Onward (im) mobilities: conceptual reflections and empirical findings from lifestyle migration research and refugee studies. Die Erde, 150(1), 1-16, 2019.

Korupp, S. E., Ganzeboom, H. B. G., and Sanders, K.: Wie die mutter, so die tochter? Dynamiken und trends im statusvererbungsprozess zwischen müttern und töchtern in Westdeutschland und den Niederlanden [Her mother's daughter? The over-time and life course dynamics of mothers' occupational status transfer for daughters in West Germany and the Netherlands]. Kölner Zeitschrift für Soziologie und Sozialpsychologie, 54(1), 1-26, doi: https://doi.org/10.1007/s11577-002-0001-5, 2002.*

Lee, N., Morris, K., and Kemeny, T.: Immobility and the Brexit vote. Cambridge Journal of Regions, Economy and Society, 11, 143-163, doi:10.1093/cjres/rsx027, 2018.

Lubkemann, S. C.: Involuntary immobility: on a theoretical invisibility in forced migration studies. Journal of Refugee Studies, 21(4), 454-475, 2008.

Mata-Codesal, D.: Is it simpler to leave or to stay put? Desired immobility in a Mexican village. Population, Space and Place, 24, doi:10.1002/psp.2127, 2018. 
Mata-Codesal, D.: Ways of Staying Put in Ecuador: Social and Embodied Experiences of MobilityImmobility Interactions. Journal of Ethnic and Migration Studies, 41:14, 2274-2290. doi:10.1080/1369183X.2015.1053850, 2015.

McCollum, D, Ernsten-Birns, A, Feng, Z, Everington, D.: Mobile no more? The innovative use of administrative data linked to a census-based longitudinal study to investigate migration within Scotland. Population Space Place, 2020, e2312 https://doi.org/10.1002/psp.2312, 2020.

Milbourne, P. and Kitchen, L.: Rural mobilities: Connecting movement and fixity in rural places. Journal of rural studies, 34, 326-336, doi:10.1016/j.jrurstud.2014.01.004, 2014.

Mulder, C.: Putting family centre stage: Ties to nonresident family, internal migration, and immobility. Demographic Research, 39, 1179. doi:10.4054/DemRes.2018.39.43, 2018.

Ortiga, Y. Y. and Macabasag, R. L. A.: Temporality and acquiescent immobility among aspiring nurse migrants in the Philippines, J. Ethn. Migrat. Stud., 47, 1976-1993, https://doi.org/10.1080/1369183X.2020.1788380, 2021.

Palomares-Linares, I. and van Ham, M.: Understanding the effects of homeownership and regional unemployment levels on internal migration during the economic crisis in Spain, Regional Studies, 54, 515-526, https://doi.org/10.1080/00343404.2018.1502420,

2020. Preece, J.: Immobility and insecure labour markets: An active response to precarious employment. Urban Studies, 55(8), 1783-1799, 2018.

Ralph, D.: Always on the Move, but Going Nowhere Fast': Motivations for 'Euro-commuting' between the Republic of Ireland and Other EU States. Journal of Ethnic and Migration Studies, 41, 176-195 doi:10.1080/1369183X.2014.910447, 2015.

Schewel, K.: Understanding Immobility: Moving Beyond the Mobility Bias in Migration Studies. International Migration Review, 54(2):328-355, doi:10.1177/0197918319831952, 2020.

Sheller, M.: The new mobilities paradigm for a live sociology. Current Sociology, 62, 811. doi:10.1177/0011392114533211, 2014.

Sheller, M., and Urry, J.: The new mobilities paradigm. Environment and planning A, 38(2), 207-226, 2006.

Stockdale, A., \& Haartsen, T.: Editorial introduction: Putting rural stayers in the spotlight. Population, Space and Place, 24(4). doi:10.1002/psp.2124, 2018.

Stockdale, A., Theunissen, N., and Haartsen, T.: Staying in a state of flux: A life course perspective on the diverse staying processes of rural young adults. Population, Space and Place, 24(8).

doi:10.1002/psp.2139, 2018.

Straughan, E., Bissell, D. and Gorman-Murray, A.: The politics of stuckness: Waiting lives in mobile worlds. Environment and Planning C: Politics and Space, 38(4), 636-655, 2020.

Vaiou, D.: Gendered mobilities and border-crossings: from Elbasan to Athens. Gender, Place \& Culture, 19(2), 249-262, 2012.

Wanner, R.: Twentieth-Century Trends in Occupational Attainment in Canada. Canadian Journal of Sociology 30(4), 441-467, 2005.*

Zühlke, S. and Goedicke, A.: Mobilität oder Immobilität? Zur Bedeutung interner Arbeitsmärkte in beiden deutschen Staaten vor 1989. [Mobility or immobility? The importance of internal labor markets in the two German states before 1989]. Kölner Zeitschrift für Soziologie und Sozialpsychologie 52, $81-95,2000 .^{*}$ 
*not considered as key papers, but used for contextualising the meaning of the term 'immobilities'

\section{B. Articles and book chapters collected via snow balling}

Barcus, H. R. and Brunn, S. D.: Towards a Typology of Mobility and Place Attachment in Rural America. Journal of Appalachian Studies, 15(1/2), 26-48, 2009.

Barcus, H. R. and Halfacree, K.: An Introduction to Population Geographies: Lives across Space. London, New York: Routledge, 2018.

Bell, M., Charles-Edwards, E., Bernard, A., and Ueffing, P. Global trends in internal migration, in Internal migration in the developed world: Are we becoming less mobile?, edited by T. Champion, T. Cooke, and I. Shuttleworth, London, New York: Routledge, 76-98, 2018.

Bernard, A., and Kolk, M.: Are Young Swedes Moving More? A Cohort Analysis of Internal Migration by Move Order. European Journal of Population, 36(3), 601-615, 2020.

Caldera Sánchez, A., and Andrews, D.: Residential Mobility and Public Policy in OECD Countries. Oecd Journal: Economic Studies, 2011(1), 1. doi:10.1787/eco_studies-2011-5kg0vswqt240, 2011.

Carling, J.: Migration in the age of involuntary immobility: Theoretical reflections and Cape Verdean experiences, J. Ethn. Migrat.Stud., 28, 5-42, doi: 10.1080/13691830120103912, 2002.

Carling, J. and Schewel, K.: Revisiting aspiration and ability in international migration, Journal of Ethnic and Migration Studies, 44:6, 945-963, doi: 10.1080/1369183X.2017.1384146, 2018.

Castles, S., and Miller, M. J.: The age of migration. International population movements in the modern world. Macmillan, Basingstoke, 1993.

Champion, A. G., Cooke, T., and Shuttleworth, I.: Internal migration in the developed world: Are we becoming less mobile? London, New York: Routledge, 2018.

Cooke, T. J.: Internal Migration in Decline. The Professional Geographer, 65, 664-675, doi:10.1080/00330124.2012.724343, 2013.

Fischer, C.: Ever-More Rooted Americans. City \& Community, 1, 177-198, doi:10.1111/15406040.00016, 2002.

Glorius, B.: Go west: Internal migration in Germany after reunification. Belgeo. Revue belge de géographie (3), 281-292., 2010.

Green, A.: Understanding the drivers of internal migration, in: Internal Migration in the Developed World? Are we Becoming Less Mobile?, edited by T. Champion, T. Cooke, \& I. Shuttleworth, London, New York: Routledge, 31-55, 2018.

Haan, M., and Cardoso, M.: Job changing and internal mobility: Insights into the "declining duo" from Canadian administrative data. Population, Space and Place, 26, e2324, doi:10.1002/psp.2324, 2020.

Kalemba, S.V., Bernard, A., Charles-Edwards, E., and Corcoran, J.: Decline in internal migration levels in Australia: Compositional or behavioural effect? Population, Space and Place, e2341. https://doi-org.uaccess.univie.ac.at/10.1002/psp.2341, 2020.

Kesselring, S.: Pioneering mobilities: new patterns of movement and motility in a mobile world. Environment and Planning A, 38(2), 269-279, 2006.

Leibert, T.: She leaves, he stays? Sex-selective migration in rural East Germany. Journal of Rural Studies, 43, 267-279, 2016. 
Leibert, T.: Wanderungen und Regionalentwicklung. Ostdeutschland vor der Trendwende? in Regionalentwicklung in Ostdeutschland, edited by Becker, S. and Naumann, M., Springer: Berlin, 199-210, 2020.

Nadler, R.: Should I stay or should I go? International migrants in the rural town of Zittau (Saxony) and their potential impact on rural development. European countryside, 4(1), 57-72, 2012.

Oedl-Wieser, T., Fischer, M., Dax, T., and Kroismayr, S.: Bevölkerungsrückgang in ländlichen Regionen Österreichs: Lebensphasen-und geschlechterspezifische Wanderungsbewegungen vor dem Hintergrund von Motiven und Lebensqualität. Austrian Journal of Agricultural Economics and Rural Studies, 27(19), 151-159, 2018.

Povrzanović Frykman, M., Guribye, E., Hidle, K., \& Mozetič, K.: How Does Place Matter to Highly Skilled Migrants?: Work/non-work experiences of international physicians in Norway and Sweden. Nordic Journal of Migration Research, 10(1), 51-68. doi: http://doi.org/10.2478/njmr-2019-0026, 2020.

Sander, N.: Germany: Internal migration within a changing nation. In Internal Migration in the Developed World, in Internal migration in the developed world: Are we becoming less mobile?, edited by T. Champion, T. Cooke, and I. Shuttleworth, London, New York: Routledge, 226-241, 2018.

Scheiner, J., Blotevogel, H., Frank, S., Holz-Rau, C., Schuster, N.: Mobilitäten und Immobilitäten: Menschen - Ideen - Dinge - Kulturen - Kapital. Essen: Klartext, 2013.

Steinführer A. and Lengerer F (2020) Von Menschen, die bleiben. Stadtbauwelt 227:42-47

Stillwell, J., Bell, M., and Shuttleworth, I.: Studying internal migration in a cross-national context, in: Internal Migration in the Developed World: Are we becoming less mobile?, edited by: Champion, T., Cooke, T., and Shuttleworth, I., Routledge, London, New York, 56-75, 2018.

Wiest, K.: Migration and everyday discourses: Peripheralisation in rural Saxony-Anhalt from a gender perspective. Journal of Rural Studies, 43, 280-290, 2016.

Wood, G., Hilti, N., Kramer, C. and Schier, M.: A Residential Perspective on Multi-Locality: Editorial. Tijdschrift voor Economische en Sociale Geografie, 106: 363-377. https://doi.org/10.1111/tesg.12158, 2015.

C. Articles collected in german geography journals, found via key word search (Die Erde, Erdkunde, Europa Regional, Geographica Helvatica, Geographische Zeitschrift, Informationen zur RaumentwicklungMitteilungen der Österreichischen Geographischen Gesellschaft, Raumforschung und Raumordnung)

Chilla, T., Morhart, T., and Braun, B.: Jenseits der Speckgürtel: Wanderungsabsichten von Schulabsolventen und der demographische Wandel im ländlichen Raum. Raumforschung und Raumordnung, 66(3), 260-270, 2008.

Glorius, B.: Gekommen, um zu bleiben? Der Verbleib internationaler Studierender in Deutschland aus einer Lebenslaufperspektive. Raumforschung und Raumordnung, 74(4), 361-371, 2016.

Hillmann, F., and Ziegelmayer, U.: Environmental change and migration in coastal regions: examples from Ghana and Indonesia. Die Erde, 147(2), 119-138, 2016.

Kordel, S.: Zuwanderung in ländliche Räume Europas: zur Diversität von rural mobilities. Europa Regional, 24(3-4), 3-15, 2017.

Sakdapolrak, P., Naruchaikusol, S., Ober, K., Peth, S., Porst, L., Rockenbauch, T., \& Tolo, V. (2016a). Migration in a changing climate. Towards a translocal social resilience approach. Die Erde, 147(2), 81-94. 
Weber, G.: Gehen oder Bleiben? Wanderungs-und Bleibeverhalten junger Frauen im ländlichen Raum. Informationen zur Raumentwicklung, 2, 225-232., 2016.

\section{Other literature}

Booth, A., Sutton, A. and Papaioannou, D.: Systematic approaches to a successful literature review. Sage, Los Angeles, London, New Delhi, Singapore, Washington DC, Melbourne, 2016.

Danielzyk, R., Dittrich-Wesbuer, A., Duchêne-Lacroix, C., Fischer, T., Hilti, N., Perlik, M., Petzold, K., Ritzinger, A., Scheiner, J., Sturm, G., Tippel, C., Weiske, C.: Multilokale Lebensführung und räumliche Entwicklungen. ARL-Positionspapier 104, Akademie für Raumforschung und Landesplanung, Hannover, available at: https://shop.arl-net.de/media/direct/pdf/pospaper_104.pdf (last access: June 2021), 2016.

Gustafson, P.: Place attachment and mobility, in: Multiple dwelling and tourism: Negotiating place, home and identity, edited by: McIntyre, N., Williams, D., and McHugh, K., CABI, Wallingford, 17$31,2006$.

Lee, E. S.: A theory of migration. Demography, 3(1), 47-57, 1966.

Wee, B. V. and Banister, D.: How to write a literature review paper?, Transport Reviews, 36(2), 278$288,2016$.

Zelinsky, W.: The hypothesis of the mobility transition. Geographical review, 219-249, 1971. 